\title{
Physical violence and alcohol drinking consumption among teenagers
}

Open acess

${ }^{1}$ Universidade de Pernambuco (UPE) - Recife (PE), Brasil

Corresponding author: amandapdc@gmail.com

Manuscript received: August 2018 Manuscript accepted: October 2018

Version of record online: November 2018
Amanda Pacheco de Carvalho', Carolina da Franca1, Valdenice Aparecida de Menezes ${ }^{1}$

\begin{abstract}
Introduction: Adolescence is a period of transition, between childhood and adulthood marked by biological, psychological and social changes. These changes characterize the situations of vulnerability to which these individuals are exposed.
\end{abstract}

Objective: The aim of this study was to examine the association between alcohol consumption and involvement in physical violence among adolescent students in the city of Olinda, Pernambuco, Brazil.

Methods: This was a pilot, cross-sectional, study conducted with adolescents enrolled in high school. The Youth Risk Behavior Survey questionnaire was applied in the classroom and questions were taken from the modules on alcohol consumption, violence and socioeconomic data. Analysis of associations was performed using the Chi-square test, or Fisher's exact test when the Chi-square parameters were not met.

Results: Involvement in physical altercations was associated with male gender $(p=0.001)$, alcohol consumption in the last 30 days ( $p=0.019)$, binge drinking $(p=0.022)$ and higher maternal education $(p=0.037)$.

Conclusion: There was an association between the consumption of alcohol by adolescents and physical violence. These results are an indication of the vulnerability to which this population is exposed and is a warning of the need for further studies to investigate this issue.

Keywords: alcohol drinking, violence, adolescent 


\section{INTRODUCTION}

Adolescence is a transition period between childhood and adult life marked by biological, psychological and social changes ${ }^{1}$. These changes highlight the position of vulnerability to which these individuals are exposed ${ }^{2}$.

Interpersonal violence is considered a public health problem. It is defined as the use of physical force or power over another individual and can result in injury, death, psychological damage and developmental problems ${ }^{3}$. One of manifestations of interpersonal violence is fighting ${ }^{4}$. In North America and Europe, the prevalence of involvement in fights among adolescents ranges from $37 \%$ to $69 \%$ for boys, and from $13 \%$ to $32 \%$ for girls ${ }^{5}$. In Brazil these percentages can vary between $17 \%$ and $32 \%$ for boys and $8.9 \%$ and $13 \%$ among girls ${ }^{6,7}$. Many factors may be considered to be determinants of their involvement in situations of violence, such as the consumption of alcoholic beverages and other drugs ${ }^{8}$.

The prevalence of alcohol consumption in the last 30 days among Brazilian adolescents is high, varying between $19 \%$ and $26 \% \%^{6}$. This percentage reaches $66.6 \%$ when considering at least once instance of alcohol consumption in their lives ${ }^{5-7}$. Considering that alcohol is the drug most consumed by adolescents and physical aggression is the main cause of mortality due to external factors in Brazilian adolescents, the objective of this study was to analyze whether there was an association between consumption of alcoholic beverages and physical violence among adolescents.

\section{METHODS}

This was a cross-sectional study, which was part of the larger project titled "Integral Attention to Adolescent Health in Public Services in Olinda".

The selection of participants was carried out randomly, using 2 stratified stages; in the first stage, the schools were drawn and in the second, the classes. Five schools and twelve classes were selected for this study, in order to guarantee heterogeneity of data. The draw of schools and classes was carried out using the Randomizer program.

A $95 \%$ confidence interval, a power of $80 \%$, an odds ratio of 1.5 , a delineation effect of 1.2 and a frequency of $50 \%$, were considered for the sample calculation of the larger project, as a result of the various risk conduit variables involved, and a 10\% increase in losses, resulting in a final sample of 1,077 adolescents. For this pilot study, 16\% of the total sample of high school students of the state public network of the city of Olinda, in the state of Pernambuco, Brazil, was enrolled.

Table 1: Consumption of alcoholic beverages among the adolescents participating in the pilot study stratified by sex. Olinda, Pernambuco, Brazil 2014.

\begin{tabular}{|c|c|c|c|c|c|}
\hline$(n=175)$ & & Total (\%) & Male (\%) & Female (\%) & p-value \\
\hline \multirow{2}{*}{$\begin{array}{l}\text { Alcohol } \\
\text { Consumption }\end{array}$} & Current alcohol consumption & 27.9 & 31.1 & 25.5 & 0.420 \\
\hline & Binge drinking & 19.9 & 21.9 & 18.4 & 0.565 \\
\hline \multirow{3}{*}{ Age at 1 st ingest } & Before 12 years old & 24.5 & 29.5 & 29.5 & \multirow{2}{*}{0.312} \\
\hline & After 12 years old & 75.5 & 70.5 & 79 & \\
\hline & Weapon charge in the last 30 days & 5.8 & 10.9 & 2.1 & 0.020 \\
\hline \multirow[t]{2}{*}{ Violence Situations } & Involvement in Body Fight & 23.3 & 35.2 & 14.3 & 0.001 \\
\hline & Involvement in body fight with serious injury & 3.5 & 5.5 & 4.1 & 0.701 \\
\hline
\end{tabular}

Data collection took place in April 2014 by administering the validated version of the Youth Risk Behavior Survey in the classrooms ${ }^{9}$. The questionnaires were applied by previously trained researchers. Participants were informed that their written responses were guaranteed to be anonymous. The time for application of the questionnaire was between 30 and 60 minutes, and it occurred without the presence of the teacher.

Alcohol consumption was analyzed based on the age of first consumption, alcohol consumption in the last 30 days and binge drinking, defined as the act of ingesting $\geq 5$ measures of alcohol on a single occasion. According to the $\mathrm{V}$ National survey on the use of psychotropic drugs among primary and secondary school students in 7 Brazilian capitals, the average age of onset of alcohol use is close to 12 years, so this was the age adopted for this variable ${ }^{10}$.

Involvement in situations of violence was analyzed based on carrying of weapons in the last 30 days, involvement in fighting in the last 12 months and involvement in fighting with serious injury (health care needed) in the last 12 months.

Data were tabulated with double input using Epidata 3.1 software. Descriptive and inferential statistical analyses were performed. Pearson's Chi-square test or Fisher's exact test were used for association analysis when the Chi-square parameters were not met. For both tests, significance was considered for values of $p<0.05$. Data analysis was performed using the Statistical Package for the Social Sciences program (SPSS) for Windows, Version 19.0 (IBM Corp., Armonk, NY, USA).

This study was approved by the Ethics Committee of the University of Pernambuco under the opinion $n^{\circ} 568.996$.

\section{RESULTS}

For this pilot study, participants were 175 adolescents regularly enrolled in high schools of the state education network, in the city of Olinda, Pernambuco, Brazil. The majority of adolescents were enrolled in regular schools (80.7\%), were between the ages of 14 and $17(71.9 \%)$, had a family income of up to $2 \mathrm{x}$ the minimum wage $(59.1 \%)$ and were female $(57.0 \%)$.

Regarding gender, there was no statistical difference in the consumption of alcoholic beverages, although the boys presented with a higher percentage of consumption than the girls. As to involvement in violence, male gender was associated with the carrying of a weapon $(p=0.02)$ and involvement in physical altercations in the last 12 months ( $\mathrm{p}=0.001$; Table 1$)$.

Pearson's Qui-square test 
Adolescents who had consumed alcohol in the last 30 days or had at some point consumed by binging showed almost twice the prevalence of involvement in physical altercations compared to those who did not consume alcohol (Table 2).

Of the adolescents whose mothers had a higher level of schooling, 39.1\% who consumed alcohol in the last 30 days were involved in a physical altercations, which represented a significant association $(\mathrm{p}=0.037)$. Despite a similar percentage of adolescents who had consumed alcohol in the last 30 days among those whose maternal schooling was of a lower level (34.8\%), a similar association was not found (Table 3).

Table 2: Factors related to alcohol consumption associated with involvement in situations of violence in the last 12 months. Olinda, Pernambuco, Brazil 2014.

\begin{tabular}{lrrrrrr}
\hline Variables $(\mathbf{n}=\mathbf{1 7 5})$ & \multicolumn{2}{c}{ Weapon charge } & $\begin{array}{c}\text { Involvement in Body } \\
\text { Fight }\end{array}$ & $\begin{array}{c}\text { Involvement in body fight with } \\
\text { serious injury }\end{array}$ \\
\hline & $\%$ & $p$ & $\%$ & $p$ & $\%$ & $p$ \\
Current alcohol consumption & 8.3 & 0.468 & 35.4 & 0.019 & 6.2 & 0.350 \\
Binge drinking & 5.9 & 0.992 & 38.2 & 0.022 & 8.8 & 0.094 \\
1st ingest before 12 years of & 7.7 & 0.634 & 34.6 & 0.281 & 3.8 & 1.000 \\
age & & & & & &
\end{tabular}

Pearson's Qui-squareand Fisher's Exact tests

Table 3: Consumption of alcoholic beverages and involvement in physical violence, according to maternal schooling. Olinda, Pernambuco, Brazil, 2014.

\section{Involvement in body fight in the last 12 months}

n

(\%)

p-value

Maternal schooling (up to 8 years of schooling) $n=85$
Current Consumption $(n=23)$
Binge Drinking ( $n=13)$
Higher maternal education (more than 8 years of schooling) $n=74$
Current consumption ( $n=23)$
Binge Drinking $(n=18)$

\section{DISCUSSION}

In general, alcohol consumption in the last 30 days and binge drinking are associated with involvement in teenage fights. Individually these risky behaviors also showed alarming percentages.

Alcohol consumption among adolescents from Olinda was high $(27.9 \%)$, and higher still among boys $(31.1 \%)$, although the gender association was not statistically significant $(\mathrm{p}=0.420)$. These percentages are in agreement with the findings of the National School Health Survey (PeNSE) ${ }^{6}$, where $25.4 \%$ of adolescents in schools in the city of Recife had consumed alcoholic beverages in the last 30 days; the levels among males and females were $26 \%$ and $24.9 \%$, respectively ${ }^{5}$. Souza et al. ${ }^{11}$. showed that $71 \%$ of adolescents had consumed alcohol at some point and $13.4 \%$ could be classified as having some degree of alcoholism.

Binge drinking was not associated with gender, demonstrating that high amounts of alcohol were consumed by both girls and boys. In the present study, one in 5 adolescents reported having taken part in binge drinking, which was less than half that found by Donath in a study of German adolescents, where one in 2 exhibited this behavior ${ }^{12}$. By comparison, binge drinking in Australian adolescents was much lower, at around $4.8 \%{ }^{13}$. This finding is alarming, excessive drinking can lead to intoxication, which in turn can increase the participation in risk taking, which can extend to behavioral problems with family, school and friends ${ }^{14}$.

$\begin{array}{lll}8 & 34.8 & 0.257 \\ 6 & 46.2 & 0.080\end{array}$

$\begin{array}{lll}9 & 39.1 & 0.037\end{array}$

$\begin{array}{lll}7 & 38.9 & 0.104\end{array}$

Although alcohol in Brazil is prohibited for children under 18 years of age, $61.6 \%$ of the adolescents in this study had already had their first contact with alcoholic beverages, with $24.5 \%$ having consumed before the age of 12 years. This result showed that experience with alcohol consumption was occurring earlier than observed in the National Survey on the Patterns of Alcohol Consumption in the Brazilian Population that found that the first contact with alcohol occurred on average at 13.6 years of age ${ }^{15}$. The prevalence of alcoholic beverage consumption tends to increase linearly with age ${ }^{11}$. Adolescents are drinking alcohol prematurely and the age of 10 - 13 years has been shown to be the most common time for the first experience with alcohol ${ }^{16}$.

To estimate the occurrence of physical violence among the respondents, 2 situations were examined. The carrying of a weapon was used as a measure of likely incitement to violence. The prevalence of gun possession was associated with males, with $10.9 \%$ of the boys reporting carrying a gun in the last 30 days. According to PeNSE6 $6.4 \%$ of Brazilian adolescents were involved in a violent situation where one person carried a firearm and $7.3 \%$ had a white weapon ${ }^{5}$. These data highlight the vulnerability to which these adolescents are exposed, reinforced by the fact that homicides represent an important percentage in the morbimortality of this group.

Involvement in fights was also a situation associated with male gender, consistent with the study by Coutinho et al. ${ }^{7}$. Boys are roughly twice as likely to engage in fights 
with physical violence, compared to girls ${ }^{8}$. These findings suggest that boys use violence as a way of resolving conflict and it reflects our cultural norms, where fighting is seen as acceptable behavior for boys ${ }^{17}$.

The association between alcohol consumption and fighting was also found in other studies conducted in South America ${ }^{2,7-9}$. Drinking alcohol can trigger violence and escalate violent situations among adolescents ${ }^{2}$. Adolescents who consume alcohol are on average twice as likely to engage in a fight as those who do not consume $e^{3,18}$. A study conducted in Mato Grosso, Brazil, found that this value could be higher than 4 times $^{19}$. Among adolescents who did not consume alcohol in the last month, $18.5 \%$ became involved in fights. Among those who consumed alcohol, this percentage was approximately double $(35.4 \%)$, and this relation was significant $(\mathrm{p}=0.019)$. Similar percentages were found in a study of Malaysian adolescents, where $40.8 \%$ of those who consumed alcohol became involved in a fight, while among those who did not drink the percentage it was $25.7 \% \%^{3}$. These results reinforce the need for better targeting of public policies aimed at this population, including discussion of this issue in schools, aiming at health promotion and prevention of alcohol consumption and physical violence.

The patterns of alcohol consumption and involvement in situations of violence are influenced by socioeconomic factors. In the present study, the association between fighting and alcohol consumption was significant for adolescents whose mothers had more years of academic study. Historically, adolescent boys, those with darker skins, and those from low socioeconomic levels are the most vulnerable to risk behaviors related to violence ${ }^{3}$. However, studies have already shown a change in this pattern, where alcohol consumption is high in all social strata and has a significant association with violence among adolescents, including middle-upperclass adolescents ${ }^{12,13}$.

The results of this study demonstrated that adolescent alcohol consumption was independent of gender, though males were more likely to be involved in fights. Current alcohol consumption and binge drinking were factors associated with involvement in fights. The existence of this association with these diseases is an indication of the vulnerability to which adolescents are exposed when they adopt risky behaviors.

The National Policy on Health Promotion has among its points of reference the reduction of morbimortality due to the use of alcohol and other drugs, and the prevention of violence and the encouragement of a culture of peace. Therefore, studies that seek to explain the association between conditions such as alcohol abuse and aberrant behaviors, such as violence, help in determining direct action that can be taken to promote the health of adolescents.

\section{REFERENCES}

1. Schoen-Ferreira TH, Aznar-Farias M, Silvares EFM. Adolescência através dos séculos. Psicol Teor Pesq. 2010;26(2):227-34. DOI: http://dx.doi.org/10.1590/S0102-37722010000200004

2. Farias CS, Martins CBG. Violência entre adolescentes escolares: condições de vunerabilidade. Enfermaría Global. 2016;(42)171-84.

3. Mat Hussin SF, Abd Aziz NS, Hasim H, Sahril N. Prevalence and Factors Associated With Physical Fighting Among Malaysian Adolescents. Asia Pac J Public Health. 2014; 26(5 Suppl):108S-15. DOI: http://dx.doi.org/10.1177/1010539514542423

4. Rudatsikira E, Mataya RH, Siziya S, Muula AS. Association between bullying victimization and physical fighting among Filipino adolescents: results from the Global School-Based Health Survey. Indian J Pediatr. 2008;75(12):1243-7. DOI: http://dx.doi.org/10.1007/s12098-008-0244-x

5. Pickett W, Craig W, Harel Y, Cunningham J, Simpson K, Molcho M, et al. Cross-national Study of fighting and weapon carrying as determinants of adolescent injury. Pediatrics. 2005;116(6):e855-63. DOI: http://dx.doi.org/10.1542/peds.2005-0607

6. Malta DC, Souza ER De, Silva MMA Da, Silva CDS, Andreazzi MAR De, Crespo C, et al. Vivência de violência entre escolares brasileiros: resultados da Pesquisa Nacional de Saúde do Escolar (PeNSE). Ciênc Saúde Coletiva. 2010;15( Supl.2): 3053-63. DOI: http://dx.doi.org/10.1590/S1413-81232010000800010

7. Silva RA, Jansen K, Godoy RV, Souza LDM, Horta BL, Pinheiro RT. Prevalência e fatores associados a porte de arma e envolvimento em agressão física entre adolescentes de 15 a 18 anos: estudo de base populacional. Cad Saude Publica. 2009;25(12):2737-45. DOI: http://dx.doi.org/10.1590/S0102-311X2009001200020

8. Cannon LRC, Serra ASL, Pereira AA, Santos Junior JD, Magalhães ML, Mota MSFT, et al. Saúde e desenvolvimento da juventude brasileira: construindo uma agenda nacional. Brasília: Ministério da Saúde, 1999.

9. Guedes DP, Lopes CC. Validação da versão brasileira do Youth Risk Behavior Survey 2007. Rev Saude Publica. 2010;44(5):840-50. DOI: http://dx.doi.org/10.1590/S0034-89102010000500009

10. Galduróz JCF, Noto AR, Fonseca AM, Carlini EA. V levantamento nacional sobre o consumo de drogas psicotrópicas entre estudantes do ensino fundamental e médio da rede pública de ensino nas 27 capitais brasileiras: 2004. São Paulo: CEBRID, 2004. 
11. Souza DPO, Areco KN, Silveira Filho DX. Álcool e alcoolismo entre adolescentes da rede estadual de ensino de Cuiabá, Mato Grosso. Rev Saúde Pública. 2005;39(4):585-92. DOI: http://dx.doi.org/10.1590/S0034-89102005000400011

12. Donath C, Graessel E, Baier D, Pfeiffer C, Bleich S, Hillemacher T. Predictors of binge drinking in adolescents: ultimate and distal factors - a representative study. BMC Public Health. 2012;12:263. DOI: http://dx.doi.org/10.1186/1471-2458-12-263

13. Mills R, Alati R, Strathearn L, Najman JM. Alcohol and tobacco use among maltreated and non-maltreated adolescents in a birth cohort. Addiction. 2014;109(4):672-80. DOI: http://dx.doi.org/10.1111/add.12447

14. Malta DC, Mascarenhas MDM, Porto DL, Duarte EA, Sardinha LM, Barreto SM, et al. Prevalência do consumo de álcool e drogas entre adolescentes: análise dos dados da Pesquisa Nacional de Saúde Escolar. Rev Bras Epidemiol. 2011;14(Supl. 1):136-46. DOI: http://dx.doi.org/10.1590/S1415-790X2011000500014

15. Laranjeira R, Pinsky I, Zaleski M, Caetano R. I Levantamento Nacional sobre os padrões de consumo de álcool na população brasileira. Brasília: 2007.

16. Maruschi MC, Bazon MR. Risco e proteção para o engajamento de adolescentes em práticas de atos infracionarios. J Hum growth Dev. 2012;22(3):348-57. DOI: https://doi.org/10.7322/jhgd.46699

17. Dias PJP, Domingos IP, Ferreira MG, Muraro AP, Sichieri R, Gonçalves-Silva RMV. Prevalência e fatores associados aos comportamentos sedentários em adolescentes. Rev Saúde Pública. 2014;48(2):266-74. DOI: http://dx.doi.org/10.1590/S0034-8910.2014048004635

18. Pierobon M, Barak M, Hazrati S, Jacobsen $\mathrm{KH}$. Alcohol consumption and violence among Argentine adolescents. J Pediatr. 2013;89(1):100-7. DOI: http://dx.doi.org/10.1016/j.jped.2013.02.015

19. Castro ML, Cunha SS, Souza DPO. Comportamento de violência e fatores associados entre estudantes de Barra do Garças, MT. Rev Saúde Pública. 2011;45(6):1054-61. DOI: http://dx.doi.org/10.1590/S0034-89102011005000072

\section{Resumo}

Introdução: A adolescência é um período de transição, compreendido entre a infância e a vida adulta marcado por alterações biológicas, psicológicas e sociais. Essas alterações caracterizam as situações de vulnerabilidade as quais esses indivíduos estão expostos.

Objetivo: Analisar a existência de associação entre o consumo de bebidas alcoólicas e envolvimento em situações de violência física entre adolescentes escolares do município de Olinda, PE.

Método: Trata-se de um estudo piloto, do tipo transversal, realizado com adolescentes matriculados no ensino médio. O questionário Youth Risk Behavior Survey foi aplicado em sala de aula e foram adotadas questões referentes aos módulos consumo de bebidas alcoólicas, violência e dados socioeconômicos. Para análise de associação foi utilizado o teste Qui-quadrado de Pearson ou o teste de Exato de Fisher quando os parametros de utilização do Qui-quadrado não eram atendidos.

Resultados: $O$ envolvimento em luta corporal esteve associado ao sexo masculino $(p=0,001)$, ao consumo de álcool nos ultimos trinta dias $(p=0,019)$, ao binge drinking $(p=0,022)$ e a maior escolaridade materna $(p=0,037)$.

Conclusão: Houve associação entre o consumo de bebidas alcoólicas por adolescentes e o envolvimento em brigas. Esses resultados são um indício da vulnerabilidade a qual a esta população está exposta e faz um alerta à necessidade de estudos que aprofundem a temática abordada.

Palavras-chave: consumo de bebidas alcoólicas, violência, adolescente.

${ }^{\oplus}$ The authors (2018), this article is distributed under the terms of the Creative Commons Attribution 4.0 International License (http:// creativecommons.org/licenses/by/4.0/), which permits unrestricted use, distribution, and reproduction in any medium, provided you give appropriate credit to the original author(s) and the source, provide a link to the Creative Commons license, and indicate if changes were made. The Creative Commons Public Domain Dedication waiver (http://creativecommons.org/publicdomain/zero/ $1.0 /$ ) applies to the data made available in this article, unless otherwise stated. 